\title{
SIR WILLIAM TRETHOWAN
}

The conferment of a knighthood on Professor W. H. Trethowan has given pleasure to his many friends throughout the College, and indeed to the entire membership. Professor Trethowan is a distinguished figure in British psychiatry and well known in many parts of the world. His wise counsel has been sought by the DHSS for many years. Both the GMC and the Medical Subcommittee of the UGC have benefited greatly from his membership.
He played a leading part in the inception of the Royal College and as first Chief Examiner launched the Membership Exam, steering it through some very choppy waters in the early years. The College has cause to be grateful to him for his statesmanlike contribution to the work of Council and of the Court of Electors.

K. RAWNSLEY

\section{WORKSHOP ON AUDIO-VISUAL TEACHING TECHNOLOGY}

The Audio-Visual Sub-Committee held a Workshop, attended by about 30 tutors from the United Kingdom and the Irish Republic at the National Audio-Visual Aids Centre in London on 14 November 1979. It was opened by the Dean of the College, Dr Thomas Bewley, and the afternoon session was chaired by Dr Edward Smith, Sub-Dean. Tony Crocker of the Centre, outlined the post-war development of A-V aids in education (the Films Sub-Committee of the RMPA was formed in 1957) and explained the work of NAVAC in demonstrating and evaluating equipment and in putting on training courses in the use of new teaching technology. A wide range of apparatus, from flannelgraphs to tape-slides, films and video, was available for participants to use themselves, and in the afternoon Paul Morby, TV producer from Birmingham University, gave a lively and very practical account of the use of TV in teaching, with particular reference to psychiatry. One discussion group looked at the potential of films and tape-slides, and in the final discussion Dr Ian Bronks of the Psychiatric Tutors Sub-Committee raised several provocative questions about possible over-concern with the technicalities of A-V teaching methods. A number of valuable points were raised and the A-V Sub-Committee was grateful for the opportunity to hear articulate guidance as to how it might direct its future activities. Our thanks are due to Messrs Geigy for subsidizing the day, which included an excellent lunch.

Tom Pilkington

Honorary Secretary,

Audio-Visual Sub-Committee.

\section{PSYCHOTHERAPY SECTION}

\section{Scientific Meetings for 1980}

$\begin{array}{ll}8.15 \mathrm{pm} & \text { Prof André Green } \\ \text { Monday, } & \text { 'Blankness'. } \\ 10 \text { March } & \\ & \begin{array}{l}\text { Middlesex Hospital Medical School, } \\ \text { Mortimer Street, } \\ \text { London W1 }\end{array}\end{array}$

London W I
$8.30 \mathrm{pm}$

Wednesday, 14 May

\author{
Dr. David Taylor \\ 'The body image, internal objects \\ and symptoms: the assessment of \\ change in psychotherapy'.
}

The Royal College of Psychiatrists, 17 Belgrave Square, London SW1

\section{News Items}

\section{University of Nottingham}

In 1977 the University of Nottingham established a Chair of Health Care of the Elderly, to which Dr Tom Arie, then Consultant Psychiatrist at Goodmayes Hospital, was appointed. Now the University has established Health Care of the Elderly as an independent Department in the medical faculty. The Department has two wings, medical and psychiatric. Each wing has its own service and facilities, but the Department functions clinically and in its teaching and research as a single team. A Senior Lecturer/Consultant 